\title{
Substitution of a Child: Features of Definition of Object and Victim of the Criminal Offense
}

\author{
Sofia Lykhova ${ }^{[0000-0003-4755-7474]}$, Tetiana Lysko * [0000-0002-0550-5740], \\ Viktoriia Sysoieva ${ }^{[0000-0003-1673-3682]}$ \\ National Aviation University, Kyiv, Ukraine \\ *bim1212@i.ua
}

\begin{abstract}
The scientific article examines the problems of determination of the victim of the criminal offense "Substitution of a child". The authors are right when argue that the object of the child's substitution is to recognize social relations that ensure the realization of the child's right to live and be raised in his family, and the right of parents to live with their child, raise him without divorce against his will. The rights of these persons may be limited only in cases specifically provided by law. The authors analyze the theoretical and practical problems of identifying the victim in the commission of this criminal offense, they provide discussions on the age of the child, who is being replaced. The authors believe that the disposition of the criminal law should provide for all possible options. Therefore, it is seen that the criminal law avoids specifying the age of the child who is being replaced or with which the replacement is being made. The instruction in the Criminal Code on the fact that only a newborn child can be replaced unreasonably narrows the content of the criminal law. A person under 18 years should be considered as a child in the context of the Art. 148 of the Criminal Code of Ukraine. The authors argue that when committing a criminal offense under the Art. 148 of the Criminal Code of Ukraine, violates not only the rights of the child, but also the rights of his parents. The purpose of this article is to identify gaps in the legal regulation of liability for the substitution of a child, as well as the search for preliminary recommendations for improving criminal law.
\end{abstract}

Keywords: substitution of a child, criminal offense against the will, object of a criminal offense, victim of a criminal offense.

\section{INTRODUCTION}

In accordance with the Part 7 of the Art. 7 of the Family Code of Ukraine (hereinafter - the FC of Ukraine), the child must be provided with the opportunity to exercise his rights, that are established by the Constitution of Ukraine, the Convention on the Rights of the Child, other international treaties, approved by the Verkhovna Rada of Ukraine. One of the important rights of a child is the right to be brought up in a family and the right to live with his parents. The Art. 148 of the Criminal Code of Ukraine (hereinafter - the CC of Ukraine) establishes liability for violation of this right - for the substitution of an anybody else's child based on mercenary or other personal motives.

It should be emphasized that the identification of the victim in the commission of this criminal offense is difficult. There are issues that need to be clarified. What is more, there is the question of the age of the child, who is being replaced. Substitution of a child violates not only the rights of the child, but also the rights of his parents.

The purpose of this article is to identify gaps in the legal regulation of liability for the substitution of a child, as well as the search for preliminary recommendations for improving criminal law.

The legal characteristic of the person of the victim in criminal law was the object of research of such scientists as S.V. Anoshchenkova, V.S. Batyrgareeva, Yu. V. Baulin, V.I. Borisov, T.I. Prysyazhnyuk, M. V. Senatorov, S.Ya. Lykhova etc. The analysis of the composition of the criminal offense "Substitution of a child" in their works was carried out by A.V. Andrushko, O.S. Kolmakova, Yu. E. Pudovochkin, A.I. Rarog, S.R. Abramova, S.S. Yatsenko, P.I. Grishaev, M.I. Melnyk, M.I. Khavronyuk, M.J. Korzhansky, M.I. Bazhanov, V.Y. Tatsiy, D.P. Evteeva, etc. Some issues concerning the criminal law protection of the morality of minors 
were considered in the works of V.V. Kuznetsov, N.O., Semchuk, V.D. Chabanyuk [1].

\section{RESEARCH METHODOLOGY}

This scientific research used a formal legal method, which allowed to classify and systematize the studied criminal law, and a method of interpretation [2-3], which allowed to clarify the content of individual rules of law. It was possible to investigate the peculiarities of the mechanism of criminal law support of certain family human rights, which are guaranteed by the Constitution of Ukraine with the help of the general scientific method of generalization. The method of abstraction [4] allowed to separate the specific manifestations of the criminal offense "Substitution of a child" and to focus on the main, the most distinctive features of the victim of the criminal offense. It should be noted that generalization and abstractions were used in combination, which allowed a more thorough analysis and study of the object of scientific research. Modeling methods and analogies were used in proposing improvements to domestic legislation in terms of establishing responsibility for substitution of a child.

The method of specific sociological research, namely the analysis of international standards, the study of case law, was used during the analysis and selection of the necessary information about the state of ensuring individual family rights and human freedoms. The method of legal statistics was used to identify the dynamics of crime in this area. Particular attention was paid to the logical legal method, which includes the means and methods of studying and interpreting the rules of law, based on the methods of formal logic. It was possible to avoid contradictions and inconsistencies in the construction of this research with the help of this method.

\section{RESEARCH RESULTS}

In 2020, the police registered 2 criminal offenses, in 2019 - 0, in $2018-1$, in $2017-0$, in 2016 - 1, in 2015 - 1, in $2014-1$, in 2013 - 1, i. e. 7 cases of substitution of a child were recorded for eight years [5]. Taking into account such a small number of criminal offenses of this type, in the scientific literature there were proposals to decriminalize this criminal offense [6, p. 195]. However, it seems impossible to support such approach, as the degree of public danger of this encroachment is quite high and entails negative consequences not only in the near future, but also in the long run. Most of such criminal offenses remain latent [7, p. 19]. In addition, the imperfection of the criminal law norm leads to incorrect qualification of the substitution of a child as a manifestation of human trafficking, committed against a minor (Part 2 or Part 3 of Article 149 of the Criminal Code of Ukraine) [8,9], non-performance or improper performance of professional responsibilities due to negligent or dishonest treatment, made by a medical worker, if it has caused serious consequences for the patient (the Part 1 of the Article 140 of the Criminal Code of Ukraine) [10].

The UN Convention on the Rights of a Child of 20 November 1989 stipulates that Member States "shall ensure that a child would not be separated from his parents against his will, except for situations when the competent authorities determine that such a divorce is necessary in the best interests of the child in accordance with applicable law and procedures in accordance under a court decision"(the Article 9), and it is established that the child "have the right to know their parents and the right to receive their care as far as it is possible"(the Article 7) [11].

The legislative construction of the Art. 148 of the Criminal Code of Ukraine provokes discussions on the object and subject of this criminal offense. The polarity of scientists' views on the object of substitution of a child should be noted, while examining the scientific literature. Some scientists believe that this is the personal integrity of a child [12, p. 280]; social relations that ensure the personal integrity of a child and its normal development [13, p. 111]; personal will of a child and a family as goods, protected by the Constitution of Ukraine [14, p. 368]; human will [15, p. 114] or social relations, arising in connection with the existence and realization of the rights of children and parents to childhood and parenthood [16, p. 9]. In our opinion, the object of the substitution of a child should be recognized as social relations that ensure the realization of the child's right to live and be raised in his family, and the right of parents to live with their child, raise him and not to divorce against his will. The rights of these persons may be limited only in cases specifically provided by law.

In the scientific literature, there are discussions on the separation of a distinct section of the Special Part of the Criminal Code of Ukraine, which should combine criminal offenses that encroach on family and marital relations and the legitimate interests of minors. This will provide comprehensive protection of the rights and freedoms, guaranteed by the Constitution of Ukraine [16, p. $9 ; 17$, p. $252-253 ; 18$, p. 187-192]. It is proposed to transfer the norm that establishes the responsibility for the replacement of a child to this section. In general, we support this approach, but it needs justification and additional argumentation. First of all, the specifics of the object of public relations should be taken into account.

Some authors argue that the child who is being replaced and the child who is used for substitution as part of this criminal offense are equivalent and are both the victim and the subject of this criminal offense in the criminal law sense. This position does not seem correct. We believe that a child cannot be identified with the subject of a criminal offense. We should talk about the victim. 
In the science of criminal law there are discussions on determining the victim of a criminal offense under the provisions of the Article 148 of the Criminal Code of Ukraine. The study of the theory of criminal law, the provisions of criminal law and the practice of its application gives grounds to argue that the victim of a criminal offense and the circumstances, associated with it, are important for the correct classification of a criminal offense, for clarifying the nature and degree of public danger and differentiation of criminal liability. Clear instructions on the victim and the circumstances, connected with him, allow to distinguish the related criminal offenses, to define constitutive signs of the structure of separate criminal offenses, promote specification of the other signs of the structure of a criminal offense. What is more, such instructions and circumstances are considered at qualification of a criminal offense and sentencing, and on release from criminal liability or punishment.

\section{DISCUSSION OF RESULTS}

Despite the fact that in the disposition of the Art. 148 of the Criminal Code of Ukraine is provided the replacement of one child, it should be clarified that the victims are both children, who are replaced. As it was rightly pointed out by A.V. Andrushko, the name of the Art. 148 of the Criminal Code of Ukraine should be formulated as "Substitution of one child for another." The scientist proposes to reflect this point in the disposition of this article [19, p. 46].

In addition, the victims are parents, whose children have been replaced. In the case of substitution, which is made by one of the parents, the victims should be both children and a family that does not know about the substitution of children.

When analyzing the composition of the criminal offense "Substitution of a child" the question about the age of the child is quite acute. According to the UN Convention on the Rights of a Child, a child is any person under the age of 18 (adulthood) (the Article 1) [11]. National legislation, defining the concept of "a child", also contains an indication that he has not reached 18 years of age (the Article 6 of the Family Code, the Articles 31-32 of the Civil Code). However, the Criminal Code of Ukraine does not contain a definition of the term "a child", which gives rise to numerous discussions in the context of defining the constitutional features of the criminal offense "Substitution of a child". Therefore, some scholars believe that under the child in the Art. 148 of the Criminal Code of Ukraine should be understood a person under 18 years of age, adhering to international standards and relying on national law [15, p. 114; 20, p. $43 ; 21$, p. 281; 22, p. 217]. At the same time Y.E. Pudovochkin clarifies that the substitution of a child is possible for any person who has not reached 18 years of age and is not aware of their origin, provided that the parents were not familiar with him [23, p. 160].
In the nineteenth century scientists used the term "baby", while analyzing the criminal offense of "Substitution of a child". Thus, A.V. Lokhvitsky claimed that child replacement is possible only for a newborn or an infant, and in exceptional cases - for older children, provided that the child and mother cannot identify each other due to certain circumstances [24, p. 490]. Nowadays, the vast majority of scientists, who have studied this issue, indicate that it may be a question of replacing only a newborn child [25, p. 383]. Others argue that it may be children, who have not been informed of the importance of substitution yet $[13$, p. $111 ; 14$, p. 368; 26, p. 99]. Thus, M. I. Khavronyuk specifies that, as a rule, it is meant a baby - a person, who cannot be identified on its individual signs by his parents or other legal representatives for some reasons (e.g. the substitution had taken place before mother was capable to remember the newborn child, or before the transfer of the child to the father in case of the death of the mother, etc.) $[14$, p. 368]. Other scholars point out that the victim of this criminal offense should be a minor under 14 years of age [27, p. 172]. Scientists substantiate the need for normative consolidation of the provision that the replacement of exactly a newborn child [28, p. 9].

In the disposition of the Art. 148 of the Criminal Code of Ukraine it is clarified that the responsibility arises for the substitution of an anybody else's child. As it is noted by A.V. Andrushko, such clarification is contained in several criminal codes of some foreign countries (the Article 172 of the Criminal Code of the Republic of Azerbaijan, the Part 1 of the Article 174 of the Penitentiary Code of the Republic of Estonia). The author concludes that this clarification was made in order to "indicate the absence of family ties between the child and the subject of this crime." However, as the author correctly points out, it is not clear from the content of the disposition of the Art. 148 of the Criminal Code of Ukraine which child is alien to the perpetrator - the one being replaced or the one, who is used for substitution. We support the position of A.V. Andrushko, that at the disposal of the Art. 148 of the Criminal Code of Ukraine it should be clarified that "responsibility arises for the replacement of an anybody else's child with another anybody else's or his own child" [19, p. 46].

\section{CONCLUSIONS}

We believe that the specific age of the child does not meter for the qualification of the act under the Art. 148 of the Criminal Code of Ukraine, but the subjective perception of family ties, realized by parents (or one of them) and a child is important. For example, if parents have not seen their child or cannot identify their individual traits, they cannot identify him as exactly their child. This is only possible for a newborn baby. If we talk about the substitution of a child under the age of 18 , the ability of parents to realize the substitution is presumed. However, we believe that a child replacement is possible 
for any child under the age of 18 , who is unable to identify himself due to dementia, has similar features to the person being replaced, or in cases where the parents have not seen the child and cannot identify their child for a long time for certain reasons. For example, a mother and child were medically separated for a long time. Another example is when a single mother dies, and the search for a legal representative takes a long time.

We believe that the disposition of the criminal norm should provide for all possible options. Theoretically, it

\section{REFERENCES}

[1] Kuznetsov, V.V. Semchuk, N.O. Chabanyuk, V.D. (2017), Criminal-legal protection of the morality of minors: a comparative legal study, Sole proprietor Kandiba T.P., Kyiv, Ukraina.

[2] Sathiya Moorthy Srinivsan, Chandrasekar Chaillah (2014), "Information Interpretation Code For Providing Secure Data Integrity On Multi-Server Cloud Infrastructure", IJMECS, vol. 6, no. 12, pp. 26-33. DOI: 10.5815/ijmecs.2014.12.04

[3] Shubhada S. Ardhapurkar, Ramandra R. Manthalkar and Suhas S.Gajre (2013), "Interpretation of Normal and Pathological ECG Beats using Multiresolution Wavelet Analysis", International Journal of Information Technology and Computer Science, vol. 5, no. 1, pp. 1-14. DOI: 10.5815/ijitcs.2013.01.01

[4] Arwa M. Aldabobi and Riad S. Jabri (2019), "Graph Abstraction Based on Node Betweenness Centrality", International Journal of Image, Graphics and Signal Processing, vol. 11, no. 11, pp. 10-17. DOI: 10.5815/ijigsp.2019.11.02

[5] Prosecutor General's Office of Ukraine, Statistical information on registered criminal offenses and the results of their pre-trial investigation, available at: https://old.gp.gov.ua/ua/statinfo.html

[6] Lisnyak, S.G. (2015), “Criminological characteristics of crimes against the will, honor and dignity of the person (2010-2014)", Bulletin of Zaporizhia National University. Legal sciences, no. 1 (II), pp. 185-195.

[7] Andrushko, A. (2018), "Substitution of children: criminological characteristics and areas of prevention", Visegrad journal on human rights, no. 5. pp. 17-22.

[8] Decision of the Pechersk District Court of Kyiv of April 1, 2020, Case № 757/11084/20-k, available at: https://reyestr.court.gov.ua/Review/88557306

[9] Decision of the Pechersk District Court of Kyiv of December 17, 2020, Right № 757/55800/20-k, available at: https://reyestr.court.gov.ua/Review/ 98150863 is possible to imagine situations when the mother (father) cannot identify her child not only the newborn, but also at a later age. Therefore, it is seen that the criminal law avoids specifying the age of the child who is being replaced or the child with who the replacement is being made. The instruction in the Criminal Code that only a newborn child can be replaced narrows the content of the criminal law unreasonably. Therefore, we believe that a person under the age of 18 should be considered as a child in the context of the Art. 148 of the Criminal Code of Ukraine.

[10] Decision of the Prydniprovsky District Court of Cherkasy of April 23, 2013, Case № 711/3175/13k. Proceedings № 1-x / 711/685/13, available at: https://reyestr.court.gov.ua/Review/50596286

[11] UN Convention on the Rights of the Child of 20 November 1989, available at: https://zakon.rada. gov.ua/laws/show/995_021\#Text

[12] The Criminal Code of Ukraine: scientific and practical commentary (2012), for the general ed. E.L. Streltsova, Odyssey, Kharkiv, Ukraina.

[13] The Criminal Code of Ukraine. Scientific and practical commentary: in 2 vols, vol. 2: Special part (2013), FOR general ed. V.Ya. Tatsia, V.P. Pshonka, V.I. Borisova, V.I. Tyutyugina. Kharkiv: Law. 1040 p.

[14] Scientific and practical commentary on the Criminal Code of Ukraine (2012), for the general ed. E. Melnyk, M.I. Khavronyuk, Legal opinion, Kyiv, Ukraina.

[15] The Criminal law (the Special part) (2012), for order. O.O. Dudorov, E.O., Written, vol. 1, Elton-2 Publishing House, Luhansk, Ukraina.

[16] Datsenko, E.V. (2015), Criminal-legal characteristic of child substitution: dissertation abstract. ... Candidate of Law: 12.00.08, Kyiv, Ukraina.

[17] Lykhova, S.Ya. (2006), Crimes in the field of realization of civil, political and social rights and freedoms of man and citizen (the Section 5 of the Special Part of the Criminal Code of Ukraine), Publishing and Printing Center "Kyiv University", Kyiv, Ukraina.

[18] Evteeva, D.P. (2015), "Issues of criminal protection of children and persons under guardianship or custody", Bulletin of the Association of Criminal Law of Ukraine, no. 1 (4), pp. 185-207.

[19] Andrushko, A.V. (2018), "Problems of criminal liability for child substitution", Scientific Bulletin of the International Humanities University, Series: Jurisprudence, no. 35, vol. 2. pp. 44-50. 
[20] Pudovochkin, Y. (2001), "Criminal liability for substitution of a child", Criminal law, no. 3. pp. 4344.

[21] Scientific and practical commentary to the Criminal Code of Ukraine (2006), resp. ed. Yazenko, S.S., A.S.K., Kyiv, Ukraina.

[22] Romanchuk, I.O. (2015), "Criminal-legal characteristics of the victim of a crime under the Article 148 of the Criminal Code of Ukraine", Bulletin of the Criminological Association, no. 3 (11), pp. 209-222.

[23] Pudovochkin, Yu.E. (2002), Liability for crimes against minors under Russian criminal law, Legal Center Press, St. Petersburg, Rossiia.

[24] Lokhvitsky, A. (1867), Course of Russian criminal law, St. Petersburg, Rossiia.
[25] Scientific and practical commentary to the Criminal Code of Ukraine (2009), for the general ed. Andrushka, P.P. Goncharenko, V.G. Fesenko, E.V., Alerta, KNT, ZUN, Kyiv, Ukraina.

[26] Qualification of crimes under investigation by internal affairs bodies (2011), for the general ed Dzhuzhi, O.M. and Savchenko, A.V., Attica, Kyiv, Ukraina.

[27] Korzhansky, M.J. (2007), Qualification of crimes: a textbook, Attica, Kyiv, Ukraina.

[28] Gul, N.V. (2009), The constitutional right to protection of the family in the criminal legislation of Russia: author's dissertation abstract on $\mathrm{PhD}$ : specialty 12.00.02, Moscow, Rossiia. 